\title{
POLÍTICA, VIDA FAMILIAR E AUTORIA FEMININA
}

\author{
POR \\ JULIANE VARGAS WELTER \\ Universidade Federal do \\ Rio Grande do Norte \\ Karina de CAstilhos LuCEnA \\ Universidade Federal do \\ Rio Grande do Sul
}

Os últimos cinquenta anos da história brasileira encerram dois grandes marcos: um regime militar violento e uma redemocratização conciliadora que deixaram marcas explícitas na história recente do país, o que pode ser inferido pelo golpe travestido de impeachment, ou seja, de legalidade, da presidenta eleita em 2014 e afastada em 2016. Esse quadro parece dar o tom da atual conjuntura brasileira com um passado que teima em reverberar no presente, acrescido de uma nova problematização: o tom misógino dos ataques sofridos pela presidenta afastada que escancara um problema estrutural da nossa sociedade.

Sendo esses uma parte dos nossos pressupostos, este artigo refletirá sobre obras de autoria feminina, a saber: os romances Fim (2013), de Fernanda Torres; Paraíso (2014), de Tatiana Salem Levy; Quarenta dias (2014), de Maria Valéria Rezende; Volto semana que vem (2015), de Maria Pilla; e os documentários Diário de uma busca (2010) de Flávia Castro; Uma longa viagem (2011), de Lúcia Murat; Elena (2012), de Petra Costa; e Os dias com ele (2013), de Maria Clara Escobar. Acrescidos a estes estão os dois romances centrais na nossa argumentação: Sinfonia em Branco (2001) e Azul-corvo (2010), de Adriana Lisboa. Trabalhar somente com autoras é um esforço deste artigo na busca por representatividade, dialogando assim com os dados que Regina Dalcastagnè apresenta chamando a atenção para o fato de que, entre 1990 e 2004, os homens representavam mais de $70 \%$ das publicações nas maiores editoras do país (147-96). Ao mesmo tempo, compreendemos que há uma socialização dos gêneros que permite não simplesmente atribuir características ditas femininas à escrita -limitando-a a condições essencialistas-, mas problematizar as construções narrativas realizadas pelas autoras aqui investigadas. Importante salientar também que a discussão aqui pretendida busca sobretudo a análise estética articulada às discussões políticas.

Isso posto, a presente análise se norteará pelos vetores expressos já no título: política e vida familiar articulados à autoria feminina. Pela análise que propomos, essa produção de escritoras contemporâneas, em cujo argumento está a matéria política nacional (em especial a ditadura civil-militar de 1964-1985), se centra em dramas 
familiares igualmente traumáticos que ocupam o centro da narrativa, legando ao trauma coletivo um lugar lateral em seu argumento. Assim, essas escritoras/diretoras não criam obras sobre a ditadura, mas sim sobre dramas e relações familiares que atravessam o trauma do regime autoritário até mesmo quando almejam escrever uma narrativa centrada naquele regime. Para a análise, mobilizaremos conceitos da psicanálise, através dos textos fundadores de Sigmund Freud, e de seus leitores atuais Márcio Seligmann-Silva, Christian Dunker e Ana Rodrigues. Desse modo, conceitos como memória e esquecimento, trauma e testemunho norteiam as nossas reflexões, sempre em articulação com a forma literária. Soma-se a esses textos a reflexão de Vladimir Safatle para pensarmos uma política dos afetos e uma sociopolítica, o que valerá para a análise central deste trabalho.

Antes de adentrar no centro da discussão, ou seja, os romances de Adriana Lisboa supracitados, como forma de ampliar o debate e dar suporte à reflexão, examinaremos os quatro romances/documentários anteriormente mencionados, exame que nos ajuda a introduzir o problema e dá o tom da questão que aqui se coloca. Se por um lado essas narrativas diferem pelas escolhas formais e temáticas, por outro, todas expõem dramas individuais que perpassam a ditadura civil-militar brasileira.

Em Fim, romance de estreia de Fernanda Torres, percorremos um marco cronológico que alcança quase todo o século XX brasileiro (de 1929 a 2014), reconstruindo a vida de cinco amigos a partir do dia de suas mortes. Com alternância de narradores-um narrador em terceira pessoa que atravessa toda a narrativa e narradores em primeira pessoa (os protagonistas) no fatídico dia final-acompanhamos uma quebra da lógica, pois o fim desses personagens expõe o caráter patético de suas vidas e não o seu caráter heróico. Assim, pelo ponto de vista de suas mortes, seguimos suas histórias (tendo como referência central a amizade entre os cinco) em um processo de reconstrução de memória marcado pelo humor e pela composição anti-heróica de si mesmo, índice corroborado pela figura do narrador em terceira pessoa.

Construído como um romance sobre o Rio de Janeiro, falamos assim de personagens que viveram a revolução de costumes proposta pela contracultura nos anos sessenta e setenta, mas sem qualquer reflexão política, sendo marcados por atitudes homofóbicas, misóginas, machistas e racistas, todas dentro de um campo do lugar-comum e travestidas de normalidade dentro da estrutura narrativa e mesmo de gênero e classe, ou seja, homens de classe média. Esse dado é central para entender a forma do romance, visto que a violência simbólica presente nessas situações é diluída no humor dos narradores, o que aponta um dado formal importante: o narrador em terceira pessoa onisciente, que abusa do discurso indireto livre, mantém a mesma linguagem e tom dos narradores em primeira pessoa (Neto, Álvaro, Sílvio, Ciro e Ribeiro), tendo como diferencial o afastamento previsto da narração em terceira pessoa e assumindo um tom menos jocoso. Reconstruindo o passado desses protagonistas, será o narrador em terceira

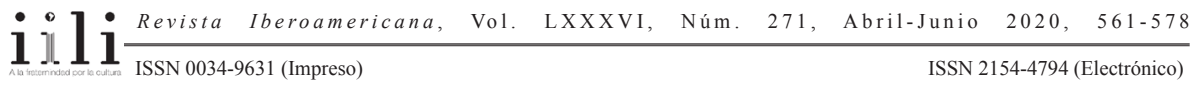


pessoa o único a mencionar dados do regime militar, por exemplo, sendo que o auge da amizade entre os cinco se dá exatamente entre os anos sessenta e setenta. E essa menção acontecerá somente na construção de duas personagens laterais, Ruth e Célia, o par antagônico: a primeira, casada com Ciro, o "boa pinta" do grupo, gostava "de Jango porque Ciro gostava de Jango, de Che, de Dylan e Noel Rosa”, ela e o marido "marcharam contra o golpe, assistiram ao Opinião com Nara e Bethânia, esconderam amigos perseguidos" (Torres 116); já a segunda, esposa de Neto, o único negro dos amigos, foi "admiradora de Médici e do general Geisel, comungava com eles do horror aos comunistas", ao mesmo tempo em que detestava as novas modas "desquites em série, a juventude drogada, os hippies de calças sujas” (Torres 129). Contudo, é Célia, que segundo seu marido era "mulata", que chamará a atenção para um dado de classe e raça: "A Ruth é sinhá. Trata a coitada [a empregada] como se fosse escrava, gosta de café na cama” (124).

Podemos inferir pela construção dos personagens que a ditadura é dado não interessante para esse recorte de classe e geração. Porém, ao mesmo tempo, se o silenciamento do dado traumático coletivo dá a dimensão de uma realidade incômoda -é possível falar dos anos sessenta e setenta no Brasil sem falar em ditadura?-duas personagens são construídas exatamente na dicotomia entre as posições políticas apagadas nos personagens masculinos centrais. Se o romance não trabalha com o regime militar como fato, falando assim de uma classe média que não participou politicamente daqueles atribulados anos, ele também problematiza o próprio silenciamento ao compor essas figuras. Se podemos simpatizar com Ruth, a culta e progressista, e antipatizar com Célia, a conservadora preconceituosa, a tensão entre classe e raça, problema estrutural que transcende a ditadura civil-militar, tensiona a questão.

Chamamos a atenção para o fato de que esses dados estão diluídos na narrativa, visto que o que dá sustentação ao romance é a trajetória mais ou menos alienada dos amigos e suas relações decompostas com esposas e filhos, e até mesmo entre si, visto que a amizade só dura de fato enquanto vivenciam o auge da revolução de costumes, traduzida por eles pelo uso de drogas e pelo sexo (marcado pela heteronormatividade). Dessa forma, os problemas estruturais da sociedade brasileira, bem como o estado autoritário, são laterais dentro dessas rememorações, que irão se centrar nas grandes aventuras vividas pelos amigos e expor suas condutas pouco louváveis que ganharão tons amenos pelo humor dos seus narradores.

Já o romance Paraíso, de Tatiana Salem Levy, é marcado por três eixos temporais e formais: o agora narrativo, que se dá na fazenda Paraíso, refúgio da protagonista Ana e narrado em terceira pessoa; o passado familiar, marcado pela ditadura civil-militar, pelo estupro da mãe, pelo assédio sofrido pela protagonista e pelas mortes precoces da irmã e da própria mãe, também em terceira pessoa e reconstruído pela rememoração; e o tempo do romance que está sendo escrito dentro do romance, assinalado pela maldição à família proclamada por uma escrava, narrado em primeira pessoa pela própria escrava.

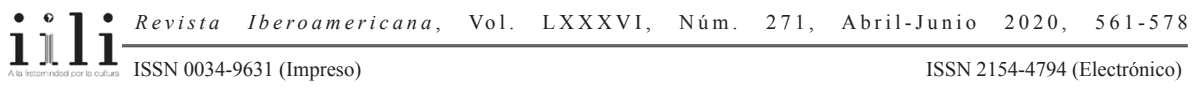


De maneira geral, Levy mescla as memórias da protagonista, marcada por dramas familiares bastante traumáticos, com um eixo narrativo que se formaliza como um romance histórico-a autobiografia da escrava-e com outro que se coloca como um novo drama-a possibilidade de estar contaminada pelo HIV e o encontro com um artista plástico no meio da mata-marcado por um romantismo entre o piegas e o mal contado. Desse modo, articula os fantasmas pessoais e o jogo de memória e esquecimento reelaborado na escrita do romance como forma de expurgar as violências e os traumas sofridos. Todo o movimento narrativo se dá a partir da possibilidade da morte da protagonista Ana (como Fim), que a faz relembrar e precisar escrever como uma forma de salvar a si mesma e, também, de certa forma, sobreviver.

Semelhante a Fim, também temos em Paraíso uma cronologia bem marcada, abarcando desde o final do século XIX até o momento atual, mas em sentido oposto ao romance anterior: se naquele os dados históricos são diluídos, configurando o caráter alienado dos personagens, aqui Levy tenta dar conta da história do Brasil nação, desde a escravidão, passando pelo Partido Comunista e pela Intentona (1935), pela Ação Libertadora Nacional (vulgo ALN), uma aliança política de setores da esquerda brasileira nos anos trinta, e a ditadura civil-militar, seguida de exílio europeu, chegando até assuntos em voga atualmente, como o feminicídio. Esses dados estão dispersos ao longo das três narrativas que compõem o romance, mesclando a ficção dentro da ficção com os fatos que aconteceram com a família da protagonista: seu pai era considerado o "maior fujão do PCdoB” (Levy 84), por exemplo, assim como relembra episódios da infância: "E na cadeia as pessoas são torturadas, como os amigos dos pais" (85). É também através da narrativa memorialística, ponto alto do romance, que temos acesso às informações sobre algumas das violências de gênero: o assédio sofrido pela protagonista, sendo o assediador seu padrasto; e o estupro da mãe em um assalto quando Ana ainda era criança. Violência de gênero que será retomada no agora narrativo: a empregada da fazenda Paraíso é espancada e esfaqueada pelo marido. Dado importante e que tensiona a situação de classe é a religiosidade da empregada e seu marido (evangélicos), fator central na composição da personagem e na relação que a intelectual branca de classe média Ana mantém com ela.

No romance de memórias, as violências materiais e simbólicas ganham caráter lírico e engendram os traumas sofridos pela protagonista, que tentam ser resolvidos no agora narrativo (que se passa na fazenda Paraíso) com a escrita de um romance (sobre a maldição da família). E é nesses dois últimos momentos que os problemas estéticos aparecem. Assim, se o romance de memórias funciona como narrativa, com um narrador em terceira pessoa que se vale das rememorações da protagonista, diluindo seus diversos traumas (individuais e coletivos) em meio à fluência do discurso, o romance histórico apresenta um grave problema, já descrito pela protagonista: ela almeja "dar voz" (Levy 20) àquela mulher, à escrava assassinada a mando da sinhá. Para além

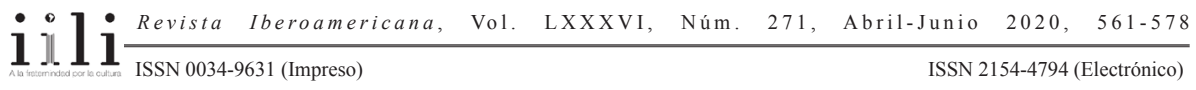


das questões de cunho histórico que podem ser problematizadas (como a captura na África), questões de outra ordem (iluminadas pelas discussões atuais sobre classe, raça e gênero) problematizam a construção. Afinal, ela, uma mulher branca de classe média do século XXI, pode "dar voz" a uma escrava do XIX? Ainda que a intenção seja dar representatividade a uma classe oprimida, ou problematizar as violências estruturais da sociedade brasileira, o romance acaba por pecar também onde se quer progressista: o carinho da escrava por seu estuprador/senhor. Segundo a escrava: "Ainda hoje, eu só saberia descrever meu sentimento pelo barão como uma mistura de amor e ódio. No início, era apenas raiva, por ele fazer comigo o que eu não queria, por me obrigar a me entregar do jeito que lhe apetecesse. Depois, foi também atração, e certa ternura. Até que Ayomide nasceu, e o amor se tornou maior que o ódio" (Levy 76).

Ao mesmo tempo, o agora narrativo, marcado pela possibilidade do HIV e o refúgio em meio à natureza, configura um encontro com um artista plástico "escandalosamente ruivo" (Levy 35) que ganha ares de romance clichê, intensificando os problemas formais e de argumento, visto que, somados aos diversos traumas da protagonista, o jovem artista também se refugia em busca da elaboração dos seus próprios traumas, no seu caso, um avô recentemente falecido que ele descobre ser um judeu fugido da guerra. Ou seja, Levy tenta dar conta de grandes traumas coletivos, mas a sua força narrativa se encontra é na individualidade de Ana e nas suas experiências, nas suas rememorações sobre a família e na tentativa de elaboração de um trauma que é seu: a relação com a irmã precocemente morta em um acidente de carro, com a mãe morta por um câncer de mama, com o padrasto assediador, etc.

Alice, a narradora-protagonista de Quarenta Dias, assim como a protagonista de Levy, escreve para elaborar a sua experiência, narrando seus traumas buscando um renascimento, para usar os termos de Seligmann-Silva ("Narrar o trauma" 66). Mas, nesse caso, a escrita em primeira pessoa e a composição em forma de diário dão o tom do caráter confessional do romance e força à narrativa. Em linhas gerais, o argumento é construído pela história de Alice, uma professora aposentada que se desloca, a contragosto, de João Pessoa até Porto Alegre para cuidar de um neto que ainda não existe. Entretanto, é abandonada pela filha, professora universitária, que parte junto com o marido para uma temporada de pós-doutorado e pesquisa na Europa. Sozinha em uma cidade e apartamento desconhecidos, a protagonista permanece quarenta dias vagando por Porto Alegre sem dar qualquer notícia à família ou aos amigos.

Se o seu périplo pode ser marcado pelo estranhamento do "exílio recente" (Rezende 201) e do ressentimento com a filha, o dispositivo que perpassa todo o romance é o desaparecimento e seu duplo correlato, a busca. Partimos dessa ideia visto que o motivo utilizado por Alice para permanecer nas ruas é a busca por Cícero Araújo, jovem paraibano, trabalhador da construção civil e filho de uma conhecida da Paraíba, que está desaparecido. Nessa busca, irá perambular pelos bairros pobres e pelo centro

\begin{tabular}{l} 
1. Revista Iberoamericana, Vol. LXXXVI, Núm. 271, Abril-Junio $2020, \quad 561-578$ \\
\hline ISSN 0034-9631 (Impreso)
\end{tabular} 
em decadência, tensionada por uma cidade assolada pela desigualdade e repleta de figuras marginais.

Esse desaparecido nos levará aos outros desaparecidos de Alice; referimo-nos aos desaparecidos da protagonista que se revelam ao longo de sua rememoração: seu pai, que "se perdeu no mundo sem dar notícia" (Rezende 166) após a morte de sua mãe e seu nascimento; seu marido, um desaparecido político; e agora Cícero, o desaparecido que faz com que ela também se torne uma desaparecida. Segundo a própria Alice: "descobria que o mundo era feito em grande parte de gente desaparecida, gente que não deu mais notícia e gente desesperada atrás ou a esperar conformadamente pelos sumidos" (118). Somam-se a eles os inúmeros personagens que Alice irá encontrar nas ruas de Porto Alegre, com destaque especial a um montonero que vive nas escadarias da Avenida Borges de Medeiros (avenida central da cidade de Porto Alegre), hoje um poeta tresloucado e miserável, que se recusa a retornar à Argentina: "Estás loca, me agarran, me matan e a todos míos, no digas nada a nadie, sai, sai daqui, loca, loca!" (237). Pela sua definição, essas pessoas que encontra nas ruas são "aves migrantes de todas as espécies, perdidas do bando, cansadas ou extraviadas a meio do caminho"(238).

A personagem também tensionará a relação entre mães e filhos, pois acompanhamos o ressentimento de Alice com a filha, o que problematiza a própria construção da maternidade. Contudo, é através do mesmo dispositivo que Alice consegue conversar com todos aqueles com quem se encontra, visto que ao acionar a personagem da mãe desesperada na Paraíba em busca de notícias do filho, todos (e principalmente todas) a escutam e tentam ajudá-la, servindo assim a maternidade como uma forma de Alice se relacionar nas ruas.

Estruturalmente, o romance se formaliza como um diário, uma "rua de papel" (175), escrito, portanto, em primeira pessoa, criando assim uma ilusão da verdade, partindo da rememoração imediata como forma de narrar, visto que a narradora começa a escrevê-lo assim que retorna de seus quarenta dias de perambulação pela cidade. Ao mesmo tempo, o caderno no qual escreve traz na capa a famosa boneca Barbie, o que a leva a dialogar com a "Barbie" em alguns momentos, humanizando debochada e ironicamente um símbolo icônico de mercado e estereótipo de gênero. Formam também o romance propagandas, comandas de lanchonetes, aviso de animais de estimação desaparecidos, etc., ou seja, papéis que a andarilha Alice teria encontrado em seu caminho e que são colocados no diário intercalados aos capítulos, reforçando a ilusão da verdade e do romance como um diário, mas também brincando novamente com esse espectro do mercado dentro da estrutura narrativa. Não menos importantes são os diálogos intertextuais, já que todos os capítulos são abertos com epígrafes, em sua maioria de autores e autoras contemporâneos (como Elvira Vigna e Lídia Jorge, por exemplo). Além do diálogo com Alice, de Lewis Carroll, explicitado pela própria protagonista.

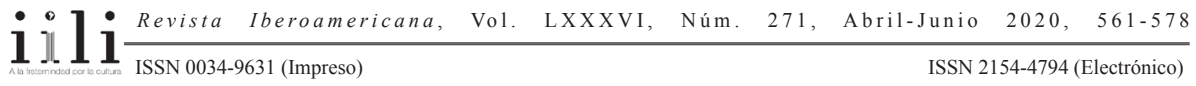


Assim como Paraíso, no qual a protagonista pretende escrever para se salvar, Alice também almeja, se não a salvação, alguma elaboração desses quarenta dias, como uma forma de dar conta da experiência, momento este traduzido por ela como um "limbo tranquilizante da escrita desenfreada" (59). Se essa escrita é um limbo, o rememorar também ganha certa dureza, pois seu escrever é construído pelo trabalho "nas tripas da minha memória" (65). Frases que reforçam o tom da elaboração do trauma e expõem a linguagem concisa, metafórica e, por vezes, dura utilizada pela autora: “Que remédio senão obedecer? Eu já estava pegando o jeito de me comportar como filha da minha filha" (74). Assim, o drama pessoal da narradora se mistura a uma série de dramas individuais que dão conta de vivências que, ao mesmo tempo em que se conectam a um trauma coletivo (a ditadura civil-militar e seus desaparecidos, um estado autoritário, uma sociedade desigual), se relacionam com questões bastante individuais de cada personagem/desaparecido com que a narradora se encontra.

Também se valerá da rememoração em primeira pessoa o romance Volto semana que vem, de Maria Pilla, mas neste caso a narrativa nasce como uma autobiografia que se transforma em um pequeno romance de memórias que a princípio, pelo argumento, poderia ser marcado por grandes traumas, mas que se ergue pela força lírica da linguagem. $\mathrm{O}$ argumento central são as memórias da própria escritora, uma ex-guerrilheira nas ditaduras brasileira e argentina, que viveu sob cárcere durante dois anos na Argentina seguindo depois para o exílio francês até os anos noventa. Porém, a narrativa é atravessada pelas lembranças familiares e cotidianas do universo da prisão.

Estruturalmente a obra é formada por vários pequenos capítulos fragmentados, marcados temporalmente-todos têm como primeiro título um ano, sendo o mais antigo 1952 (Maria Pilla nasceu em 1946) e o mais recente 2011-que não seguem uma ordem cronológica. Esse caráter permite, assim, que tenhamos acesso não apenas às vivências da narradora, mas também aos episódios políticos que perpassam a sua experiência. Entretanto, se o romance poderia ser marcado por um grande trauma coletivo (a ditadura civil-militar) e um individual consequente da violência (a tortura), somos surpreendidos pelo tom empático e bem resolvido dessas memórias. Esse tom permite por vezes que essa narradora em primeira pessoa se afaste da matéria narrada quase como uma terceira pessoa que revela nos detalhes a riqueza lírica dos momentos vividos no agora rememorado.

Dessa forma, são marcantes alguns episódios da narrativa que desvelam a linguagem utilizada por Pilla, como o episódio das rabanadas, que ocorre na prisão de Olmos (Argentina) em 1975, um evento feito pelas próprias detentas da prisão na "comemoração" de um ano de encarceramento: "Uma receita sem ovo. Nunca mais achei que rabanada precisasse de ovo. O cheiro da fritura do leite com açúcar iluminava o rosto de cada uma". Ou ainda o episódio das melancias, no qual durante dois anos se polemizava na prisão qual seria o peso da fruta. Segundo a narradora, pesar "uma

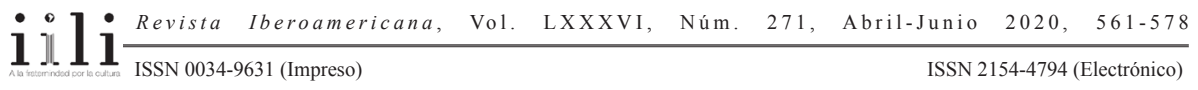


melancia foi uma de minhas primeiras iniciativas ao deixar a prisão", na "mesma noite escrevi a minha amiga contando a novidade. Queria compensar suas lágrimas sentidas nos bate-bocas dos dois anos de detenção. Dois anos em que fiquei em cima do muro, sem tomar partido naquele que era o grande debate em Olmos e, depois, também em Devoto" (86-87).

Essa linguagem e a narração do cotidiano da prisão dão conta do tipo de memória e testemunho de Pilla sobre aquele que seria um grande momento traumático, mas que é diluído na leveza do seu olhar sobre o cotidiano. Importante atentar para os pressupostos de Seligmann-Silva neste caso: essas são construções sempre presentificadas ("Narrar o trauma" 69), ou seja, é o presente que norteia esse passado. Ao mesmo tempo, não há qualquer cena de tortura, o que pode nos levar a inferir que não há lembranças sobre esses episódios ou, ainda, que na seleção dessas memórias, esses momentos não foram cruciais. Ou ainda, que o silenciamento sobre essas lembranças dá conta do próprio trauma. Contudo, a tortura emerge da narrativa somente como um sonho fragmentado (45-46), em um capítulo intitulado 2003, ao melhor estilo freudiano de elaboração do trauma ("Além do princípio do prazer" 13-160; "Recordar, repetir e elaborar" 193-228).

Misturado ao lirismo empático da narradora com o seu cotidiano prisional, somamse as suas relações familiares, com as lembranças do suicídio de Getúlio Vargas e do caos em Porto Alegre, e de seu pai, um antigetulista convicto. É exatamente esse pai que será responsável pelo título do romance no, provavelmente, último diálogo que tiveram ao vivo: "Ué, guria, pra onde tu vai? O pai vestia um pijama claro, estava em pé, na cozinha. Eu deveria sair por uns dias. Quis exagerar para não assustar. Uma semana e estaria de volta. Pôxa, tanto tempo assim? É. Mando notícias. Mais de dez anos se passaram até eu voltar àquela cozinha" (Pilla 19). A figura paterna será retomada no exílio, no episódio na Torre Eiffel, em 1981, após sua morte precoce, aos 58 anos, e um dos pontos fracos do romance: segundo a mãe, "minha militância é que tinha matado o pai” (65). Este momento, que era para ser novamente marcado por uma grande tensão, é resolvido de maneira relativamente simples, e, talvez, artificial, na construção narrativa: "Falei que pensar o que ela pensava criava discórdia entre nós, uma atmosfera de culpa, e que isso era o que a ditadura queria: dividir, separar do convívio os diferentes" (65), afirmação que a mãe aceita, com a descrição de uma cena simples no topo da torre Eiffel, com uma "paisagem incrível” (65).

Também no cinema brasileiro contemporâneo, a autoria feminina tem se ocupado do tema político em paralelo com os dramas familiares. Diretoras de diferentes gerações lançaram recentemente documentários em que recuperam a trajetória de familiares que, de alguma maneira, sofreram as atrocidades da ditadura civil-militar brasileira. ${ }^{1}$

Tudo indica que a produção de documentários sobre o tema seguirá crescendo, em especial depois do impeachment de Dilma Roussef que, aliás, foi acompanhado de perto por cineastas brasileiras (ver Lis y Calgaro).

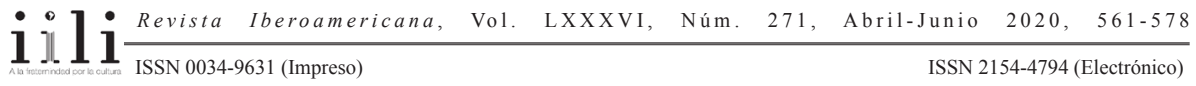


Salientamos que esses documentários são permeados de relações subjetivas que permitem inferir de antemão que problematizam a ideia de documento real e verídico, visto que são elaborações que passam por buscas de um passado traumático coletivo (a ditadura), mas sobretudo de um passado traumático individual (a morte do pai, o suicídio da irmã, o exílio do pai, o exílio forçado do irmão). Em outras palavras, esses "documentos" estão tensionando o rememorar/esquecer, trabalhando com memórias individuais marcadas por relações afetivas, sendo assim "narrados" em primeira pessoa em uma atitude reflexiva das diretoras sobre a obra e sobre si mesmas. Se a memória é um dispositivo central na forma de todas essas obras, buscas por resoluções do passado são suas grandes máscaras. Segundo Martins e Machado, "Partir de uma ausência íntima (de um irmão, de um pai) parece ser a característica de boa parte da produção documental recente. À falta de imagens, documentos, de verdade, soma-se a lacuna íntima" (81). Assim, partindo dos escritos de Freud, se é sempre com perdas que a memória traumática é obrigada a confrontar-se, esses documentários realizam o próprio trabalho de luto ("Luto e melancolia" 170-94). ${ }^{2}$

Diário de uma busca, de Flávia Castro, traça o percurso íntimo (diário) da diretora na tentativa de compreender a estranha morte do pai, o militante de esquerda Celso Afonso Gay de Castro, perseguido e depois exilado nos anos 1970. Segundo o laudo oficial, Celso Castro tentou assaltar o apartamento de um suposto ex-oficial nazista e, fracassado o plano e vendo que seria preso, se suicidou, tudo isso em Porto Alegre, em 1984. A filha-diretora-narradora entrevista amigos do pai, policiais e peritos que acompanharam de perto o caso e conduz o filme para uma espécie de salvação da memória de Celso: os amigos lembram sua liderança na resistência à ditadura; os policiais-todos meio patéticos-estão ali para mostrar as arbitrariedades do período, embora nada confessem; o perito, também sem afirmação categórica, deixa entrever que o caminho da bala que matou Celso descartaria a hipótese de suicídio. Mas se por um lado a condução da filha valoriza a figura paterna-sem cair em sentimentalismo, vale lembrar-, os depoimentos da mãe e do irmão garantem a discordância de ponto de vista, um dos pontos altos do documentário. A mãe da diretora, Sandra Macedo, companheira de militância de Celso, como ele perseguida e exilada, mostra-se bemresolvida quanto ao episódio (fria, para quem adere ao ponto de vista da diretora). Ao falar com a filha sobre Celso, Sandra faz questão de lembrar das vezes em que ele abandonou os filhos, não pagou pensão, além de narrar o envolvimento dele com a luta armada em tom debochado. É claro que foi a diretora que optou por manter esses depoimentos da mãe no documentário, num intento de postular a personalidade do pai como contraditória, mas no balanço geral do filme, prevalece a admiração da filha.

2 Para um estudo mais apurado da relação entre cinema e psicanálise, ver os cinco volumes da coleção Cinema e psicanálise coordenada por Christian Dunker e Ana Rodrigues, em especial o volume 3 Filmes que curam e o 5, História, gênero e sexualidade.

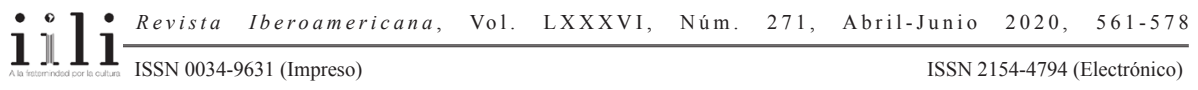


Outra voz dissonante é Joca, irmão de Flávia, que fala da vergonha que sentiu do pai, morto em circunstâncias, no mínimo, esquisitas. Uma das cenas mais emblemáticas do filme é uma discussão entre os irmãos sobre o documentário, ou, em outras palavras, sobre a memória do pai.

Nesses pareceres desencontrados sobre Celso Castro está a força do filme, ou seja, na família que, quase trinta anos depois da morte de Celso, rememora o trauma reelaborando-o, cada integrante a sua maneira. Logo, o centro está nas marcas que a morte deixou nos filhos, em especial na filha diretora; a militância de Celso e as práticas autoritárias do governo militar brasileiro impulsionam o problema todo, mas são laterais na construção do documentário.

Ainda mais lateral, embora marcante, é a presença do tema político em Elena, sensível longa de Petra Costa. Sabemos que o pai da diretora, mencionado mas ausente, é um político mineiro, e que ele e a mãe, essa sim presente e central no filme, não terminaram na guerrilha do Araguaia, porque a mãe descobriu-se grávida de Elena, irmã da diretora que se suicidou em Nova York, em 1990. O quanto esse suicídio tem relação com a infância nômade que os pais militantes impuseram a Elena é difícil de mensurar, mas o silêncio da diretora sobre o pai político pode indicar que o tema ainda fere.

De todo modo, o nervo do filme está nessas três gerações de mulheres-Petra, Elena e a mãe-e como Petra e a mãe se unem para superar o trauma da morte de Elena. Nesse processo, elas presentificam Elena, seus diários, gravações, objetos; encenam sua vida, refazem seu percurso em Nova York. Talvez nessa encenação esteja oculto um intento não enunciado da diretora: evitar que a mãe, visivelmente deprimida, refaça a história da filha suicida. Esteticamente, o documentário é dos mais bem realizados, delicado, sensível e forte, numa lógica que lembra os romances de Adriana Lisboa que comentaremos adiante.

Dois suicídios, dois pais ausentes-um morto, outro deliberadamente esquecidoduas mães eloquentes, duas diretoras tentando entender suas famílias, famílias estas que carregam na memória o período militar. Os dias com ele, de Maria Clara Escobar, sai um pouco da curva que traçamos entre Diário de uma busca e Elena. Nele está presente o trauma familiar derivado da ditadura, mas o tom do documentário é muito mais seco, provavelmente porque o pai da diretora-o ex-professor universitário e dramaturgo Carlos Henrique Escobar-está presente no filme. Fica visível a distância entre pai e filha; a diretora chega a enunciar que o objetivo do documentário é recuperar a história do importante intelectual, preso, torturado, exilado e, ao mesmo tempo, entendê-lo como pai, essa figura afastada da formação de Maria Clara e com a qual ela se encontra e tenta compreender. O pai envelhecido, duro, silencioso, sarcástico, se destaca no filme, e ficamos com a sensação de que o intelectual foi resgatado, mas a relação pai e filha continua fraturada.

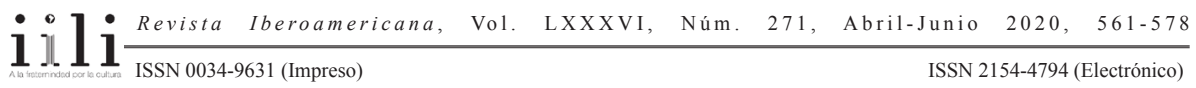


Já o documentário Uma longa viagem, de Lúcia Murat, também deriva diretamente do regime militar, ainda que não se queira um filme sobre ele. Murat é figura bastante conhecida e premiada no cinema brasileiro, tendo feito um dos mais sensíveis filmes sobre o regime militar e a participação feminina, o emblemático Que bom te ver viva (1989). Contudo, tendo ela mesma participado da luta armada, o foco do seu argumento é seu irmão caçula, Heitor, que, em 1968, durante o regime militar, foi mandado em viagem para a Europa como forma de evitar que também se envolvesse na militância. Ao mesmo tempo, o documentário é concebido como uma forma de lidar com a morte de um outro irmão, Miguel, um médico infectologista envolvido em causas humanitárias e adorado pelos irmãos.

Intercalando imagens de Caio Blat, intérprete de Heitor na juventude, e imagens atuais do irmão, acompanhamos a sua adesão à contracultura, através de cartas lidas durante o filme, e o trauma da família, ao lidar com uma provável doença mental desse irmão, que chega a ser internado no final dos anos setenta. Mas aqui, diferente do desbunde do romance de Fernanda Torres, no qual a contracultura é encarada apenas como puro hedonismo, desprovido de caráter político, Heitor a leva até as últimas consequências, viajando ao redor do mundo (incluindo Índia e Nepal) e abusando de drogas alucinógenas que talvez tenham lhe deixado graves consequências. Durante as viagens do irmão, Lúcia, a diretora-irmã, chega a ser presa, ficando encarcerada de 1971 a 1974, passando por sessões de tortura física e psicológica. ${ }^{3}$ A prisão é mencionada ao longo da narrativa, mas é lateralizada frente ao drama do irmão vivo, que vive sob medicação até hoje, e o trauma de lidar com o irmão morto.

Até agora acompanhamos os suicídios e os pais ausentes nos filmes de Flávia Castro e Petra Costa, bem como as mães eloquentes e tão presentificadas na construção narrativa. Acompanhamos também o pai apenas materialmente presente no longa de Maria Clara Escobar. Lúcia Murat, por sua parte, dilui essas figuras centrais maternas e paternas entre os irmãos, ocupando ela mesma um lugar materno frente ao irmão caçula e medicado que não consegue elaborar o trauma da morte do outro irmão. Nesse quadro, de retomada de contracultura e problematização de normatividades, a irmã-diretora tenta elaborar para e com ele esse drama individual que é também seu, ficando assim os traumas do regime (ainda que deflagradores da juventude nômade de Heitor) lateralizados frente ao drama da família.

Sendo assim, esperamos ter deixado claro que no corpus de autoria feminina aqui comentado, o dado político brasileiro, em especial a referência à ditadura civil-militar, está presente no enredo/roteiro, mas não em posição central já que nesta está o drama familiar derivado do dado político ou intercalado com ele. Obviamente, essa síntese

Para maiores informações ver o depoimento de Lúcia Murat à Comissão Nacional da Verdade em 2013 ("Depoimento").

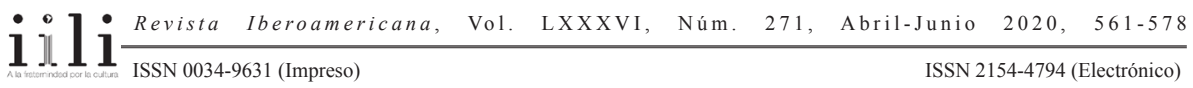


pode ser generalista e esconder as especificidades de cada romance ou documentário, mas em termos gerais cabe afirmar que a vida familiar está em destaque nas obras aqui analisadas.

Por fim, é importante chamar a atenção para as datas de produção dessas obras, que se dão a partir de 2010. No campo externo, falamos de obras que já têm como horizonte histórico a composição da nossa tardia Comissão Nacional da Verdade, instituída oficialmente em 16 de maio de 2012. ${ }^{4}$ Ou seja, há nesse (e neste) momento uma demanda dentro do campo político pela rememoração, uma institucionalização do rememorar, em contraponto ao esquecimento proposto anteriormente através da Lei de Anistia de 1979. ${ }^{5}$ Se a princípio se pode pensar que são políticas tardias que poderiam não ter grande impacto social e, talvez, muito menos, estético, ao mesmo tempo, ao olhar para essa produção recente o regime militar retorna em meio aos dramas familiares, ainda que de maneira lateral. Ou seja, falamos de obras bastante contemporâneas e que trazem dados novos: o primeiro, a crescente produção que se vale do regime ditatorial para construir os romances, ou, pelo menos, situa suas narrativas dentro dessa marca cronológica, bem como o número de documentários que se apropria do tema; e a crescente produção de escritoras/diretoras, algo que vai ao encontro de uma expansão do mercado e de um debate crescente sobre gênero que temos acompanhado principalmente ao longo dos últimos anos.

Sinfonia em Branco, premiado romance de Adriana Lisboa, foi publicado em 2001. Vem chancelado por Pilar del Río, autora do prefácio e presidenta da Fundação José Saramago, que concedeu à autora o prêmio de melhor romance em 2003, quando Saramago ainda vivia. Atesta Pilar del Río no prefácio: "a Sinfonia em branco que Adriana Lisboa escreveu sendo quase uma menina e cativou um escritor que já era mais velho e mais sábio. Portanto, este livro leva o selo Prêmio José Saramago. Nada mais, nada menos" (Lisboa 10).

Nascida em 1970 no Rio de Janeiro, Adriana Lisboa é dos nomes mais interessantes da atual literatura brasileira. Sua formação intelectual segue a regra de grande parte dos escritores da sua geração, qual seja, autores pós-graduados em literatura, com diplomas de mestrado e doutorado das grandes universidades do Brasil e do exterior. No entanto, a autora escapa de um outro modelo também de sua geração: sua ficção, em especial os dois livros que analisamos aqui, não se detém nos impasses da criação literária, aos protagonistas escritores, ao romance dentro do romance, à famosa metaliteratura. Talvez o que a destaque da média da literatura brasileira contemporânea seja sua habilidade de, sendo especialista em literatura, praticar uma ficção para especialistas

4 A Comissão Nacional da Verdade teve como finalidade apurar violações de direitos humanos ocorridos entre 1946 e 1988 (ver “A CNV”).

5 Para maiores informações ver Lei $n^{\circ} 6.683$. 
e não especialistas, que transita por temas de interesse geral, como são a política e a vida familiar, dois vetores que percorremos neste artigo.

Em Sinfonia em branco está a narração de uma violência aterradora: o pai que estupra a filha. Mas, à semelhança do que observamos no documentário Elena e no romance Volto semana que vem, a forma estética pende mais para o lirismo do que para a rudeza. No livro, mais que a denúncia artificial de uma violência extrema (artificialidade presente em Paraíso, por exemplo), está a narração em terceira pessoa, o discurso indireto livre certeiramente empregado para ingressar nas consciências dos personagens e mostrá-los em sua humanidade (ou falta de) sem cair em didatismo ou pieguice. O episódio do estupro ilustra o uso sofisticado da técnica narrativa:

Naquela tarde, ele veio. Um homem adulto, maduro, inteiro. Um homem. E uma menina que queria ser menina, apenas.... Um homem. Entrou em seu quarto e sentou-a sobre o colo dele e ela não teve medo, a princípio, porque aquele homem era seu pai. Os dois riram. Conversaram um pouco. Ele lhe acariciava as mãos. Ele lhe acariciava os braços. Os ombros. Os seios. ... A mão de um homem sobre um seio alvíssimo. A pele virgem. O bico que ele rodava como se desse corda a um relógio. A mão de um homem sobre a barriga tão lisa de Clarice e aquela respiração que resfolegava odiosa e as calças dele onde um volume aparecia vindo não se sabia de onde. O fecho ecler que ele abriu com a mão direita enquanto a mão esquerda inflamada procurava alguma coisa entre as coxas dela. Clarice dócil recatada submissa educada polida discreta adorável. Ele faria aquilo de novo. E de novo. E de novo. E de outras maneiras. (Lisboa 271-73)

A cena terrível ganha força pelo uso preciso dos adjetivos, as frases curtas ritmadas, as repetições, um narrador que marca a violência do ato descrevendo em vez de enunciar. O talento na construção do narrador e das personagens, no tom da narrativa, exacerba a temática brutal garantindo que temas extremamente difíceis (estupro, tentativa de suicídio, parricídio) apareçam com a seriedade que exigem, mas despertem empatia, reflexão e afeto.

Em relação à matéria que perseguimos neste texto-como a autoria feminina cruza política e vida familiar-, há neste romance um movimento semelhante ao que identificamos nos livros/filmes anteriores. No centro do enredo está a família esfacelada pelo pai mas, ao expor o corpo violado de Clarice, o narrador compara esse corpo feminino ao dos presos políticos torturados durante a ditadura e ao das crianças abandonadas à própria sorte:

Que coisas estariam reservadas para ela própria [Clarice]? Para Maria Inês? Para seus pais? Como se chamava o inferno que vigia sobre a terra, à luz da razão dos homens? Nos corpos das moças violadas por seus próprios pais? Nos corpos torturados dos presos políticos? Nos corpinhos cheios de verminose e bichos-de-pé das crianças que trabalhavam a roça de sol a sol? (Lisboa 289-90)

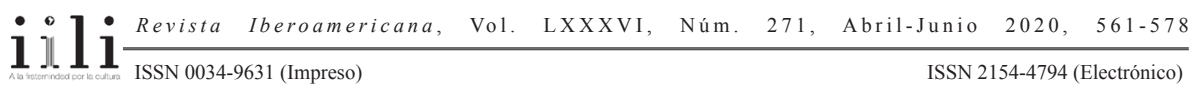


Nesses corpos violados está a passagem do trauma individual para o coletivo, e o silêncio de Clarice pode espelhar o silenciamento brasileiro sobre a ditadura civilmilitar e sobre a pobreza extrema de parte considerável da população. Para Safatle, pensar a política é pensar em um circuito dos afetos e suas implicações, avançando para além da separação entre individual e coletivo (17), tendo como pressuposto central que não há política sem corpo (22). Assim, esse circuito de afetos coloca a experiência subjetiva no centro da análise, para além de uma dicotomia que separe norma e fato, interno e externo. A subjetividade produz sua objetividade que, por sua vez, determina a afetação dos indivíduos.

Nessa linha, em artigo recente sobre greves feitas por mulheres na Argentina e na Polônia (a primeira, como forma de protesto contra um estupro; a segunda, como forma de manter a lei do país sobre o aborto, ou seja, ambas sobre os corpos femininos), Eliane Brum sintetizou: “O corpo das mulheres atravessa-e é atravessado-pelo poder e pela política”. A afirmativa de Brum se relaciona diretamente com a proposta de Safatle e com o enunciado de Lisboa: o corpo individual é também ele coletivo, o que é intensificado pelo seu caráter feminino. Ou seja, a política está na vida familiar, o corpo (especialmente o feminino) é político, a subjetividade perpassa a compreensão dos grandes problemas históricos. Dessa forma, as violências estão inscritas nos corpos e nas temporalidades, indo além do grande evento público, já que inscritos nos dramas privados. Por essa ótica, a coletividade nada mais é do que um grande indivíduo no qual todos os elementos individuais continuam presentes.

Há ainda um outro fragmento do romance de Lisboa que corrobora a não centralidade do regime militar nestas narrativas. Trata-se da história dos pais de Tomás, lateral dentro do drama de Clarice, mas que legitima, salvo engano, as relações entre o corpo de Clarice, a ditadura e a miséria:

Seus pais também já não estavam mais: haviam voltado do Chile com a Abertura e morrido com calma e sem sonhos vários anos depois. Viveram o suficiente para lutar pelas Diretas já, e o suficiente para enfim votar para presidente em 1989. Ainda eram comunistas. Morreram comunistas. E Tomás, que nunca havia se engajado na luta, surpreendera-se votando no candidato do PCB naquele 15 de novembro. Lembrava-se disso agora. (Lisboa 185-86)

Tomás é um artista apaixonado por Maria Inês, irmã de Clarice, que hoje vive em casa vizinha à de Clarice, partilhando dos seus silêncios e do que poderíamos chamar de um auto-exílio, já que escondidos e isolados na antiga fazenda da família. Se o regime autoritário não é central para a construção do romance, a associação entre os corpos marcados pela violência física (de violação sexual em Clarice, pelo Estado na ditadura, pela sociedade desigual brasileira) dão a dimensão de uma violência que é estrutural e estruturada, e que passa da subjetividade à objetividade. 
Contudo, Azul-corvo (2010) traz o dado histórico de maneira mais aparente e se articula ao drama dos militantes políticos que foram os pais de Tomás. A princípio, o romance poderia ser resumido de maneira bastante simples: menina, Evangelina (mais conhecida como Vanja), de 13 anos, perde a mãe e embarca em uma viagem em busca do pai verdadeiro. Para isso contará com a ajuda de Fernando, ex-marido da mãe que mora no Colorado, e Carlos, um pequeno imigrante ilegal de El Salvador. Tudo isso tendo como cenário o contraste da zona sul carioca (na qual Vanja viveu até os 13 anos) com o deserto do Colorado estadounidense, seu novo lar.

Entre os deslocamentos da protagonista e dos personagens secundários, articulados com a violência estrutural a que muitos desses imigrantes estão expostos e o olhar estrangeiro dos personagens sobre os Estados Unidos, a narrativa pode ser lida como um romance de migrações e errâncias ou um romance sobre a busca do pai. Mas a sua força reside em outros pontos: nos processos reconstitutivos da memória de Vanja e Fernando, ex-guerrilheiro e desertor do Araguaia; e na linguagem formalizada na voz da narradora, que conta essa história anos depois. Nesse caminho, Vanja vai reconstruir muito da nossa história recente, que é também memória afetiva da mãe falecida e da infância distante no Brasil relacionada à memória coletiva e de Fernando. Suas elaborações sempre manterão o tom reflexivo, "Será que as casas têm memórias?" (Lisboa, Azul 193), ou inventivo, "se as pessoas não me forneciam detalhes, eu tinha o direito moral de providenciá-los" (Azul 45), de certa forma teorizando ela mesma as suas recordações que são também do Outro (a mãe, Fernando) e são também nossas (a ditadura civil-militar, a guerrilha do Araguaia). Assim como são também memórias oficiais: "Era preciso matar a história. Matar a memória e alguma consciência com gordurinhas inconvenientes" (Azul 207).

Dessa forma, é no que teoricamente é lateral-as memórias de Fernando-que se ergue um romance também sobre o anti-heróico desertor e a guerrilha do Araguaia fragmentariamente apresentado junto ao romance da protagonista. Assim, é a partir da memória terceirizada de Vanja e de suas reflexões (que são geracionais), "Mas as coisas têm um rosto distinto quando vivemos o pós-elas. Quando nascemos tantos anos depois. Quando precisamos que nos informem, que nos expliquem, que nos digam que era óbvio o óbvio que pulou dentro dos arquivos" (Azul 44), que teremos acesso à história de Fernando, vivendo em um auto-exílio pós-Araguaia. Narrativas essas que misturam ficção e vida real ${ }^{6}$ e se intercalam com o seu drama pessoal: a busca do pai, a perda da mãe.

Para além da belíssima linguagem metafórica já expressa no título do romance (Azul 29, 41), chama a atenção um campo semântico bastante explorado e diluído ao

${ }^{6}$ As narrativas expostas em Lisboa $(81,82)$ podem ser encontradas nos relatórios da Comissão da Verdade (ver “A CNV”). Bem como dos textos em itálico (Lisboa 85, 86, 163, 206) pode inferir-se que são também trechos de documentos.

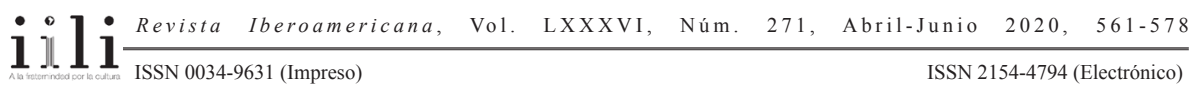


longo da narrativa. Remetemos aqui às escolhas lexicais que se referem, em maior ou menor grau, a um horizonte ditatorial, mas agora realocadas em outros contextos. São expressões como "ditadura do espaço" (22), ao se referir à paisagem dos EUA; "cadáveres desovados" (24), ao se referir às montanhas cariocas; "às vezes as pessoas somem” (36), ao falar sobre a sua árvore genealógica, em uma articulação muito própria do nosso regime, o desaparecido político; ou ao se referir a sua escola americana vazia no período de férias: "Talvez ali dentro fossem conduzidas pesquisas militares ou mantidos arbitrariamente presos políticos" (39); ou, ainda, sobre a sua nova condição: "Existia uma luta ali, uma guerrilha interna" (54); ou ao falar das mudanças de temperaturas na cidade, taxada por ela como uma "revolução" (104); ou em um diálogo entre Fernando e o pai de Carlos, sobre a presença da polícia de imigração em sua casa, quando "o pai de Carlos contou a história como se fosse um preso político ansioso para colaborar e evitar a tortura" (123); ou ainda nos jogos de palavras com os vocábulos "deserto" e "desertar" proposto pela narradora $(147,216)$; ou ao relacionar uma indisposição estomacal de Carlos com "uma pequena guerrilha. Uma minirrevolução” (197).

O regime militar e seu campo semântico perpassam o romance, mas não de forma a representar e construir um romance sobre a ditadura ou sobre o Araguaia, e sim diluídos ao longo do processo de amadurecimento e de reconhecimento da própria narradora através de sua história e da delicadeza com a qual se refere a essas histórias que se cruzam com a sua:

Eu o enterrei, um ex-Fernando debaixo do chão. E junto com ele, sua ex-vida, suas ex-memórias que, por mais que ele compartilhasse, seriam sempre e somente suas e de mais ninguém. O que ele sentiu na mata, o que ele sentiu no pub londrino, o que ele sentiu deslizando sobre a lama congelada em Pequim. O que ele sentiu ao abraçar Manuela/Joana, Suzana, Isabel. O que ele sentiu antes e depois desses abraços. Ao desertar dessas mulheres ou ao ser desertado por elas (desertar: tornar deserto, abandonar, despovoar; deixar de estar presente; desistir, renunciar). $\mathrm{O}$ que pensou, o que planejou e não fez, o que prometeu e não cumpriu, o que fez sem ter planejado antes, o que não desejou e conquistou assim mesmo. (Azul 216)

Sendo o trauma constitutivo dos sujeitos, bem como a literatura marcada pelo seu presente traumático, expondo assim o seu caráter testemunhal (Seligmann-Silva, Literatura e trauma 77), lidamos aqui com marcas que são individuais, mas que se articulam ao seu chão histórico. Ou dito de outra maneira, subjetividades que formam a nossa coletividade, para usar os termos de Safatle. Não por acaso em muitas dessas obras o fazer artístico (a escrita de um romance, o fazer documental) é ele mesmo o artifício utilizado para lidar com esses traumas. Se para Freud o silenciamento advém do processo traumático (Além do princípio do prazer 13-160), os documentários, por exemplo, tentam vencê-lo, elaborando suas narrativas pessoais que perpassam as

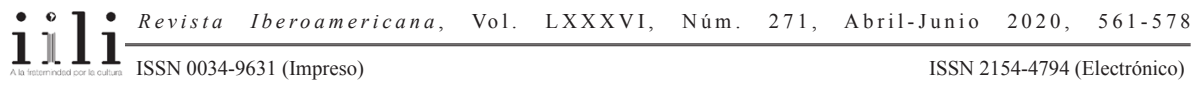


coletivas. Ao mesmo tempo, os romances também partilham desse índice: escrever ou contar como forma de elaborar. Chamamos atenção para o fato de que é somente em Sinfonia em branco que o silenciamento é total, sendo que talvez ele engendre o trauma individual mais violento, o corpo violado, mas que acaba por se conectar a todos os outros corpos violados.

Assim, partilhando dos pressupostos de Christian Dunker (Mal-estar, sofrimento e sintoma 19-46) e articulando, dessa forma, as discussões estéticas às psicanalíticas, refletimos sobre a literatura como uma forma de elaboração de sofrimentos da realidade contemporânea brasileira que lida com seus índices históricos, ou seja, um país desigual e que carrega consigo um passado recente traumático. Porém, nas narrativas aqui analisadas, esse passado coletivo não é o crucial do drama apresentado: são as relações afetivas e subjetivas, marcadas pela vida familiar, que ocupam o centro da narrativa. Ainda que elas tenham sido deflagradas pelo regime militar (Volto semana que vem, Diário de uma busca, Meus dias com ele) ou mantenham com ele paralelismos (Fim, Paraíso, Quarenta dias, Elena, Uma longa viagem, Sinfonia em Branco e Azul-corvo), o trabalho estético dessas escritoras e diretoras acaba por revelar dramas privados que atravessam os coletivos. Os traumas se mostram, dessa maneira, dimensões multifacetadas nas quais se articulam a singularidade e subjetividade do corpo e as grandes narrativas de catástrofe, reelaborando uma nova dimensão do político na sociedade brasileira.

\section{OBRAS CITADAS}

Brum, Eliane. "Mulheres, corpo e insurreição". El país. 24 out. 2016. <http://brasil. elpais.com/brasil/2016/10/24/ opinion/1477313842_805785.html>.

“ACNV”. Comissão Nacional da Verdade. < http://www.cnv.gov.br/nstitucional-acessoinformacao/a-cnv.html>. 10 julho 2016.

Dalcastagnè, Regina. Literatura brasileira contemporânea-um território contestado. Vinhedo: Editora Horizonte, 2012.

Diário de uma busca. Flávia Castro, dir. Vídeo Filmes, 2010.

Dunker, Christian. Mal-estar, sofrimento e sintoma. São Paulo: Boitempo, 2015. eAna Lucilia Rodrigues. Cinema e psicanálise. Vols. 1-5. São Paulo: Versos, 2015.

Elena. Petra Costa, dir. Busca Vida Filmes, 2012.

Freud, Sigmund. “Além do princípio de prazer". Obras completas. Vol. 14. 1920. São Paulo: Companhia das Letras, 2010.

"Luto e Melancolia". Obras completras. Vol. 12. 1917. São Paulo: Companhia das Letras, 2010.

"Recordar, repetir e elaborar: novas recomendações sobre a técnica da psicanálise II”. Obras completas. Vol. 10. 1914. São Paulo: Companhia das Letras, 2010.

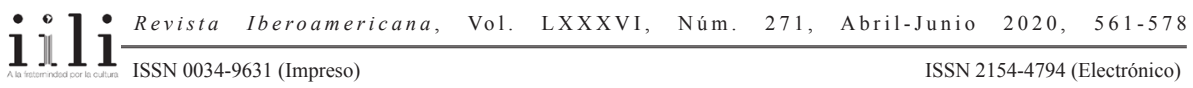


Lisboa, Adriana. Azul-corvo. Rio de Janeiro: Objetiva, 2014.

Sinfonia em branco. Rio de Janeiro: Objetiva, 2013.

"Lei N ${ }^{\circ}$ 6.683, de 28 de agosto de 1979". Presidência da República: Casa Civil. <http:// www.planalto.gov.br/ccivil_03/leis/L6683.htm>. 27 out. 2016.

Levy, Tatiana Salem. Paraíso. Rio de Janeiro: Foz, 2014.

Lis, Laís e Fernanda Calgaro. "Cineastas gravan documentários no senado sobre Impeachment de Dilma". Globo.com. 30 ago. 2016. <http://gl.globo.com/ politica/processo-de-impeachment-de-dilma/noticia/2016/08/cineastas-gravamdocumentios-no-senado-sobre-impeachment-de-dilma.html>. 23 out. 2016.

Martins, Andrea França e Patrícia Machado. "Imagem-performada e imagem-atestação: o documentário brasileiro e a reemergência dos espectros da ditadura". Galaxia Online 28 (2014): 70-82.

Murat, Lúcia. "Depoimento de Lúcia Murat à Comissão da Verdade do Rio". A Tarde. 28 mayo 2013. <http://atarde.uol.com.br/politica/noticias/1506981-depoimentode-lucia-murat-a-comissao-da-verdade-do-rio>. 16 out. 2016.

Os dias com ele. Maria Clara Escobar, dir. Vitrine Filmes, 2013.

Pilla, Maria. Volto semana que vem. São Paulo: Cosac Naify, 2015.

Rezende, Maria Valéria. Quarenta Dias. São Paulo: Alfaguara, 2014.

Safatle, Vladimir. O circuito dos afetos: corpos políticos, desamparo e o fim do indivíduo. São Paulo: Cosac Naify, 2015.

Seligmann-Silva, Márcio. "Narrar o trauma-A questão dos testemunhos de catástrofes históricas". Psicologia Clínica 20/1 (2008): 65-82.

"Literatura e Trauma: um novo paradigma". O local da diferença: ensaios sobre memória, arte, literatura e tradução. São Paulo: Editora 34, 2005. 63-80.

Torres, Fernanda. Fim. São Paulo: Companhia das Letras, 2013.

Uma longa viagem. Lúcia Murat, dir. Vitrine Filmes, 2011.

Palavras-chave: Vida familiar; trauma; exílio; memória

Recebido: $\quad 31$ outubro 2016

Aprovado: $\quad 15$ maio 2017

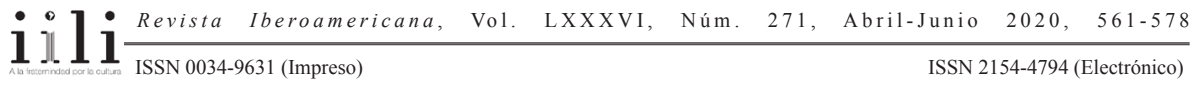

